DOI: $10.5817 / \mathrm{SPh} 2017-1-8$

\title{
Vzpomínka na profesora Lubomíra Nového
}

\section{A Memory of Professor Lubomír Nový}

\author{
Jiří Svoboda
}

\begin{abstract}
Abstrakt
Jsem rád, že mohu přispět ke vzpomínání na profesora Lubomíra Nového, a vážím si toho, že jsem mohl být jedním z mnoha jeho studentů. Lubomír Nový dokázal koncem šedesátých let spolu se svými kolegy vytvořit na Katedře dějin filosofie brněnské Filosofické fakulty pro nás studenty velmi vstřícnou atmosféru. On sám v ní vynikal především svým dynamismem. Zkouška u něho nebyla jednoduchá, protože byla současně školou kladení otázek a hledání odpovědí. Myslím, že toto kladení otázek a hledání odpovědí bylo jeho celoživotním krédem. Díky němu byl také jednou z profilových osobností tvưrčího filosofického myšlení u nás v letech šedesátých. A tvưrčí osobností zůstal i v letech devadesátých, tedy po návratu ke své profesi po vynucené odmlce.
\end{abstract}

\section{Klíčová slova}

Lubomír Nový - profesor filosofie, učitel, vzpomínka

\begin{abstract}
I am glad that I can contribute to the commemoration of professor Lubomir Novy and I appreciate that I had the chance to be one of his many students. Lubomir Novy was, together with his other colleagues, able to create a very friendly environment for us students. He stood out with his dynamism. His exams were not easy, because it was always a lesson in creating questions and searching for answers. I think that this "creating questions and searching for answers" was his lifelong attitude. Thanks to this, he was one of the main personalities of philosophical thought in this country in the sixties. He remained creative even in the nineties when he returned to his profession after an enforced break.
\end{abstract}

\section{Keywords}

Lubomír Nový - professor of philosophy, teacher, memory 
Vzpomínám na profesora Lubomíra Nového jako jeden z mnoha jeho studentů. Bude to tedy vzpomínka ponejvíce osobní. Vážím si jednak této př́iležitosti a jednak toho, že jsem profesora Nového mohl jako student poznat. Když jsem v roce 1967 přišel na Katedru dějin filosofie naší Filosofické fakulty, čekalo mě a mých dvanáct dalších kolegů v kruhu něco úžasného. Vedle toho, že jsme začali být vpravováni do tajů oboru, který jsme si vyvolili, to byli ti, kteří nás do těch tajů vpravovali. Nevím, jestli by se mnou s odstupem času všichni kolegové souhlasili, ale troufám si říct, že v tehdejším složení katedry působil profesor Macháček jako úctyhodný solitér a že mimořádné oblibě se těšila sestava našich učitelů ve složení Jiří Cetl, Jiří Gabriel, Karel Hlavoň, Pavel Materna a Lubomír Nový. Uvedl jsem je podle abecedy, protože jinak to nejde. Míra jejich oblíbenosti se nedá porovnávat, byl to sehraný tým, který nám studentům vytvořil na katedře prostředí, o kterém bych klidně mohl říct, že to bylo prostředí rodinné. Role byly samozřejmě rozdány. Přísnost a náročnost na jedné straně a odpovědnost - mnohdy spíš taková ta studentská odpovědnost - na straně druhé. Ale šlo vždy o otevřený a vstř́ícný vztah.

Každý z této sestavy byl jiný. Lubomír Nový byl podle mého soudu charakteristický nejvíce svou dynamičností. Vzpomínky studenta se mi mísí i se vzpomínkami pracovními, protože později jsme se mohli setkávat i při společném odborném zájmu. A mohu říci, že kdykoliv profesor Nový přišel, byl konec klidu. Vždy jste mohli očekávat otázku, o které bude třeba diskutovat, a to až do jejího vyčerpání. A vůbec to nemusely být otázky přímo filosofické, mohly to být i otázky všedního dne. Diskutovat a vidět věci z různých pohledů, to je to, co mi profesora Nového nejvíce připomíná. A jeho neklid, který podle mě pramenil z jeho dynamismu.

Ke studentským vzpomínkám určitě patří katedrové poznávací zájezdy. Jejich program býval třídenní a myslím, že jeho tvůrcem i gestorem v průběhu jeho konání byl Jiř́i Gabriel. Ten má Českou republiku perfektně propojenou s jejími historickými ději i osobnostmi. U ostatních našich učitelů to bylo určitě také tak, ale zatímco někteří studenti následovali Jiřího Gabriela například na prohlídku hradu, někteří zůstávali s Lubomírem Novým v podhradí a diskutovali. To byla svěží dělba úkolů a nemyslím, že bych touto poznámkou nějak zlehčoval role obou našich učitelů.

Jako elév na začátku studia se člověk někdy až později dostane k tomu, aby vedle literatury, kterou musí zvládnout ke zkoušce, studoval také odbornou tvorbu svého učitele. U Lubomíra Nového to bylo něco jiného. V době, kdy jsme nastoupili na fakultu, měl za sebou mimo jiné dvě publikace, v nichž vyjádřil svoje přesvědčení tvořivého marxisty o tom, jak je třeba překonat 
dogmatičnost marxismu: Filosofie v neklidné době z roku 1965 a Marx v NSR $\mathrm{z}$ roku 1967.

Ve Filosofii v neklidné době způsobem sobě vlastním vyložil, jak by bylo možné překonat schematismus oficiálního marxismu. Schematismus spočívající např. v postupu, že se vybere vhodný př́klad, který se dosadí do poučky, a že správností tohoto prríkladu poučka potvrdí správnost sebe samé. Zatímco konkrétní člověk a životnost filosofie se ztrácejí. K myslitelům, o které se Nový ve své práci opírá, patří například Garaudy, jeden z jeho oblíbených francouzských filosofů, s nimiž jsme se takto mohli seznámit. K základním chybám marxismu, které zde Nový uvádí, patří odtržení marxistické filosofie od dědictví minulosti, mechanický výklad boje materialismu s idealismem, jednostranný poměr k Hegelově filosofii, ale i absence dialogu, polemiky či rozboru nemarxistických směrů myšlení, jaké představují např. Kierkegaard, fenomenologie, existencialismus, dialektická teologie, soudobá marxologie atd. Kdybych měl použít nějakého alespoň trochu obrazivého přirovnání, pak jsem jako elév studia mohl nahlédnout, že termín mladý Marx se netýká jen věku tohoto myslitele.

Nepatřil jsem nikdy k pohotovým diskutérům, a tak pro mě byla zkouška u Lubomíra Nového a Jiřího Cetla, která plnila funkci jakéhosi postupového klíče, hodně perná. Skládala se samozřejmě z mnoha dílčích otázek, o kterých bylo třeba diskutovat. Zdařilo se, dobrá, ale co si člověk mohl odnést jako výsledný pocit, bylo určitě to, že nikdy není dost pozic, ze kterých máme věci nahlížet.

Profesor Nový patřil mezi přední organizátory vědeckého života u nás. Také to se projevovalo v jeho vlivu na nás studenty. Díky jeho osobnímu zaujetí např́íklad pro institucionální diskusi s prostředím formovaným protestantstvím jsme mohli na Filosofické jednotě v Brně koncem šedesátých let (nevím už přesně, v kterém roce to bylo) slyšet hovořit doktorku Boženu Komárkovou, která nám poskytla vhled do témat moderního protestantismu. Profesor Nový byl členem Vědeckého kolegia filosofie a sociologie ČSAV a předsedou komise pro dějiny filosofie. V roce 1968 organizoval např. celostátní konferenci Strukturalismus a historismus ve filosofii 20. století a zúčastnil se XIV. Mezinárodního filosofického kongresu ve Vídni, o rok později byl přijat za člena Mezinárodního filosofického ústavu v Paříži.

Na jeho členství v tomto institutu byl u nás brán zřetel až v roce 1990, tedy po dlouhé době, kdy se nemohl z politických důvodů věnovat své původní profesi. V červnu roku 1970 byl jako revizionista vyřazen z vědecké a pedagogické práce a na Filosofické fakultě mohl působit jako odborný pracovník 
Laboratoře sociologických výzkumů. Nikoli už jako učitel, pro kterého byl tak typický živý styk se studenty. A když, tak jen v omezené míře: pokud si dobře vzpomínám, v roce 1972 se podílel na několikadenním sociologickém výzkumu využití volného času obyvatel středního Slovenska. Jako tazatelé v terénu jsme tenkrát působili my studenti. Každovečerní vyhodnocování průběhu výzkumu a jeho výsledků byla pro nás další škola, kterou jsme mohli s naším učitelem zažít.

Jak už jsem uvedl, měl jsem možnost setkávat se s profesorem Novým i v době pro něho velmi nepříznivé. Mimo jiné to bylo i pro můj zájem o meziválečné osobnosti českého protestantismu, jejichž studiu se Lubomír Nový dlouhodobě věnoval. Téma porovnání tří osobností tohoto období - Kozáka, Rádla, Hromádky - je pro studium českého protestantismu stěžejní. Vzpomínám si, jak Nový reagoval na můj náhled na vztah těchto osobností k Masarykovi. Myslím, že bude nejlepší, když uvedu jeho reakci doslovně: To je trochu průšvih. Ale pak následovala diskuse, za kterou jsem mu dodnes vděčný.

Potud tedy vzpomínky studentské. V roce 2009 pořádala Katedra filosofie bratislavské filosofické fakulty konferenci na téma „podoby filozofovania včera a dnes“. Bylo to téma pěkně otevřené a já jsem se tam pokusil připomenout právě Nového Filosofii v neklidné době. A to jako výraz autorova hledačství, jeho otevřenosti, schopnosti sebereflexe a v bezpodminečné neukončenosti kladení otázek! Jak ji ve své práci predikuje. To v šedesátých letech působilo jako nakročení, kterým marxistická filosofie směřovala do slibných výšek a působila jako svěží a nadějný vítr. Ten utichl po roce 1968.

Pokusil jsem se ale také představit Nového jako filosofa devadesátých let, kdy témata let šedesátých už byla překryta něčím jiným. Mám zde na mysli jeho projekt emergentního univerzalismu, který formuloval např́klad ve své stati Evropský diom jako budova a jako domov. Nový zde reaguje na současnou situaci západního světa s břitkostí jemu vlastní. „Partikularismus je posilován protiuniverzalismem, pluralismem a relativismem, jenž se uplatňuje v diskusich o postmoderně, snažicích se - alespoň negativně - najít výraz pro přlomovost doby: Bůh je mrtev, člověk je mrtev. I neosobni struktury, a také Hegel a Marx je mrtev a dalši „velká vyprávěni“. Trochu moc mrtvých, hřbitov ideji! Jsme doba poststrukturalistická, postmaterialistická, postnáboženská, postindustriálni atd. - zkrátka postmoderní. Nikdo si již nemůže činit nárok na majitelstvi pravdy a dobra. "1

1 L. Nový, Evropský dům jako budova a jako domov (od partikularismu k emergentnímu univerzalismu), SPFFBU, B 41, 1994, s. 9. 
V této situaci pocituje Nový absenci syntetizující filosofie člověka post-istické doby a je přesvědčen, že nestačí pouhá negace partikularismu. Uznává nutnost nějakého univerzalismu, který ale musí:

- Odmítnout fundamentalismy, vycházet z vědomí toho, že jistý nás přesahující řád existuje. Že je, ale co je a jak je, o tom lze do nekonečna diskutovat z hlediska nejrůznějších náboženství nebo z hlediska laického. Avšak dodržovat důsledný ekumenismus a nepřipustit svaté války.

- Pochopit, že obecně civilizační proces je vždy zprostředkován specifickými dílčími historicitami, které se ve styku s jinými blíží obrysům konsensu. To nazývá Nový univerzalismem zdola - emergentním univerzalismem.

Projevem současného emergentního univerzalismu může být soubor lidských a občanských práv. Často nedokonalý či porušovaný, ano i rozporuplný, přesto však přijímaný jako soubor regulativních idejí. Nový odmítá totální relativismus a je přesvědčen, že jsme schopni rozlišovat dobré a zlé a že jisté vyšší hodnoty zkrátka platí

Na závěr mi dovolte ještě jednu poznámku. Lubomír Nový zastával filosofii šikmého střihu (věnoval jí mimo jiné samostatnou stat’ v revui Host v roce 1995). Převedena do velmi stručné podoby vypadá asi takto. Všude najdeš slušné lidi a všude jsou... Negativní opozitum si může každý dosadit podle libosti. Je velmi lidským vyjádřením autorova hledačství a otevřenosti, se kterou přistupoval ke každodennímu životu i k teoretickým otázkám filosofie.

\author{
PhDr. Jiří Svoboda, CSc. \\ Katedra filozofie, Filozofická fakulta, Masarykova univerzita \\ Arna Nováka 1, 60200 Brno \\ Česká republika \\ jirisv@phil.muni.cz
}

